\title{
Influence of microcrystalline cellulose in thermoplastic starch/polyester blown films
}

\author{
Mônica Oliveira Reis ${ }^{*}$, Juliana Bonametti Olivato ${ }^{1}$, Juliano Zanela ${ }^{1}$, Fábio Yamashita ${ }^{1}$ and \\ Maria Victoria Eiras Grossmann ${ }^{1}$ \\ 'Departamento de Ciência e Tecnologia de Alimentos, Centro de Ciências Agrárias, \\ Universidade Estadual de Londrina - UEL, Londrina, PR, Brazil \\ *monicareis09@gmail.com
}

\begin{abstract}
This work investigated the influence of microcrystalline cellulose (MCC) in thermoplastic starch/poly (butylene adipate-co-terephthalate) films produced by blown extrusion, using different MCC contents (4, 7 and $\left.10 \mathrm{~g} .100 \mathrm{~g}^{-1}\right)$. The films were characterised for their mechanical, structural and barrier properties. Increasing fibres concentration reduced the tensile strength $(6.9$ to $4.6 \mathrm{MPa})$, the elongation at break (568 to $147 \%$ ) and weight loss in water $(12.8$ to $11.1 \%)$ of

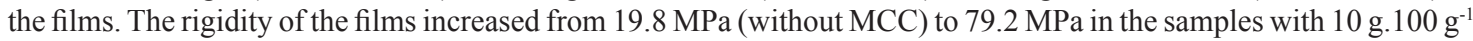
of MCC. SEM images showed the occurrence of some agglomerates in this sample. The water vapour permeability of the films was not affected by the presence of MCC. The production of starch/PBAT/MCC films by blown extrusion was successful; however some adjustments are necessary to improve the dispersion of the particles at the polymeric matrix.
\end{abstract}

Keywords: extrusion, cellulosic fibres, biodegradable films, polyester.

\section{Introduction}

In the last years, there was an increase in the researches focused in the development of biodegradable materials, due the growing accumulation of the conventional plastic materials, which are hard to be decomposed. Biodegradable polymeric packaging derived from cellulose, proteins and starch $^{[1-4]}$ have gained a great impulse because they allow the reduction of the use of materials derived from petroleum.

The starch is the most used agro-resource to produce biodegradable films due their biodegradability, low cost and wide availability ${ }^{[5]}$. According to Teixeira et al. ${ }^{[6]}$ and Tang and Alavi ${ }^{[7]}$, the native starch is not a real thermoplastic, but however, in the presence of a plasticiser, high temperatures and shear, it melts and flows, forming a material called thermoplastic starch (TPS).

The TPS, however, when used as a single polymer to produce biodegradable materials presents some restrictions that limit their use, including their hydrophilic character with high water vapour permeability and deficient mechanical properties, which are dependent of the relative humidity of the environment ${ }^{[7,8]}$. To overcome these drawbacks, TPS is frequently blended with biodegradable synthetic polymers ${ }^{[9-12]}$, as poly (butylene adipate-co-terephthalate) (PBAT), an aliphatic-aromatic copolyester that combines desirable performance properties with biodegradability ${ }^{[13,14]}$.

The inclusion of cellulosic fibres in biodegradable matrices has been the focus of numerous studies, with the aim to improve the mechanical and barrier properties of the materials ${ }^{[4,15-19]}$. Müller et al. ${ }^{[16]}$ studied the effect of cellulose fibres $(0.10,0.30$ and $0.50 \mathrm{~g}$ fibres/g starch) in the mechanical and physicochemical properties of starch-based films produced by casting. Their results showed that more resistant (8.39 MPa) and rigid (Young's modulus of $217 \mathrm{MPa}$ ) films were produced with the addition of the fibres, but with a lower elongation at break (22\%), when compared to the material containing no fibres (1.59 $\mathrm{MPa}, 21 \mathrm{MPa}$ and $83 \%$, respectively).

Microcrystalline cellulose (MCC) presents as an alternative to the vegetal fibres used in biodegradable films. The MCC is a purified and insoluble cellulose produced by partial acid hydrolysis of the wood cellulose. The hydrolysis occurs in the amorphous areas of the polymeric chain, followed by the separation of the released microcrystals, which corresponds to a highly crystalline cellulose ${ }^{[20-22]}$. The use of MCC in different biodegradable polymeric materials has been studied ${ }^{[18,23-25]}$.

Sun et al. ${ }^{[18]}$ developed poly (vinyl alcohol) (PVA)/MCC composites by injection moulding. The Young's modulus of the plasticised PVA increased from 204.8 MPa to 731.2 MPa, with the addition of $20 \%$ of MCC. The tensile strength increased from $37.8 \mathrm{MPa}$ (PVA/MCC-0) to $46.5 \mathrm{MPa}$ (PVA/MCC-20), which confirmed the strong interfacial interaction and good dispersion between MCC and PVA.

While the injection moulding and the production of films by casting are less exigent process in relation to the structuration of the polymeric matrix and their interaction with the fillers, this does not occur with the blown film production. In this case, the requirements concerning the compatibility, dispersion, fibre/matrix adherence and the capacity of the fibres to transmit the tension along the material are greater, and the content of the added fibres has an important effect. To the best of our knowledge, our previous work $^{[24]}$ is the only study about blown films with MCC in blends of thermoplastic starch/polyester. The aim of this work was to produce biodegradable films based on thermoplastic starch/PBAT/MCC by blown extrusion and evaluate the influence of higher concentrations of MCC in their properties. 


\section{Materials and Methods}

\subsection{Materials}

The blown films were produced with native cassava starch (17\% wt amylose, 13 g. $100 \mathrm{~g}^{-1}$ moisture), (Indemil, Guaíra, Brazil), poly (butylene adipate-co-terephthalate) (PBAT), supplied by BASF (Ludwigshafen, Germany) under the commercial name Ecoflex ${ }^{\circledR}$, microcrystalline cellulose (MCC) M 101 Avicel®, supplied by Hexus Food Ingredients (Portão, Brazil), with a particle size of 10-15 $\mu \mathrm{m}$ and aspect ratio around 1, and glycerol, supplied by Dinâmica (Diadema, Brazil).

\subsection{Methods}

\subsubsection{Blown films production}

The materials were processing using a laboratory co-rotating twin-screw extruder (BGM, model D20, Taboão da Serra, Brazil) with screw diameter (D) of $20 \mathrm{~mm}$ and length/diameter (L/D) ratio of 34 . The TPS/MCC/PBAT pellets were produced in two steps. In the first step, TPS/MCC pellets were produced by dispersing the MCC in distilled water for 3 min with the aid of an Ultra Turrax homogeniser (MARCONI, model MA 102, Piracicaba, Brazil), which was then added to the starch and glycerol and manually mixed before extrusion. The mixture was pelletised using a temperature profile of $90 / 120 / 120 / 120 / 120^{\circ} \mathrm{C}$, screw speed of $100 \mathrm{rpm}$, and a matrix with five $2-\mathrm{mm}$ holes. The venting ports were maintained closed to avoid water evaporation. In the second step, the produced TPS/MCC pellets were processed with the PBAT with the same process conditions to produce TPS/MCC/PBAT pellets.

To obtain the blown films, TPS/MCC/PBAT pellets were fed to a single-screw extruder (BGM, model EL-25, Taboão da Serra, Brazil) composed of a 25-mm diameter screw with an $\mathrm{L} / \mathrm{D}$ ratio of 30 . The barrel temperature profile used was $90 / 120 / 120 / 130{ }^{\circ} \mathrm{C}$ for the four zones and $130{ }^{\circ} \mathrm{C}$ for the 50-mm film-blowing die and screw speed of $40 \mathrm{rpm}$. The process conditions (screw speed and temperature profiles) were defined according to Reis et al. ${ }^{[24]}$. The pellets and the blown films were produced in duplicate.

The proportion of the components in each sample is presented in Table 1. The control sample (MCC0), without MCC, contained 56 g. $100 \mathrm{~g}^{-1}$ of TPS ( $27 \mathrm{~g}$ glycerol $/ 100 \mathrm{~g}$ starch) and 44 g. $100 \mathrm{~g}^{-1}$ of PBAT. The concentrations of MCC (expressed as \% w/w, TPS/PBAT basis) were selected in preliminary tests. The inclusion of water $(2.4 \mathrm{~mL} / \mathrm{g}$ MCC $)$ was necessary to improve the dispersion of MCC and the used content was the minimum required to promote this dispersion. Before the mixture with starch and glycerol, none free water was visible being the MCC hydrated and swollen.

The film thickness was controlled by the roll speed and the air-flow rate. The average thickness of the films was of $164 \pm 17$ to $195 \pm 6 \mu \mathrm{m}$.

\subsubsection{Mechanical properties}

A texture analyser model TA.XT2i (Stable Micro Systems, Goldaming, England) fitted with a $50 \mathrm{~kg}$ load cell was used to conduct the tensile tests of the films. Tensile tests were based on ASTM method D-882-02 ${ }^{[26]}$. Ten samples from each formulation were cut along the longitudinal direction (50 $\mathrm{mm}$ in length and $20 \mathrm{~mm}$ in width) and fit in the tensile grips. The crosshead speed was set at $50 \mathrm{~mm} . \mathrm{min}^{-1}$ and the initial distance between the grips was $30 \mathrm{~mm}$. Before testing, the samples were conditioned at $23 \pm 2{ }^{\circ} \mathrm{C}$ and $53 \pm 2 \%$ relative humidity $(\mathrm{RH})$ (saturated solution of $\mathrm{Mg}\left(\mathrm{NO}_{3}\right)_{2}$ ) for $48 \mathrm{~h}$. The tensile strength ( $\mathrm{MPa})$, elongation at break (\%) and Young's modulus $(\mathrm{MPa})$ were determined.

\subsubsection{Density}

To determine the films density, three samples from each formulation with $20 \mathrm{~mm} \times 20 \mathrm{~mm}$ were kept in a desiccator with anhydrous calcium chloride $\left(\mathrm{CaCl}_{2} / 0 \% \mathrm{RH}\right)$ for 2 weeks and then, were weighed according to the procedure described by Müller et al. ${ }^{[27]}$.

\subsubsection{Water Vapour Permeability (WVP)}

The tests were conducted using the American Society for Testing and Materials ASTM E-96-00 $0^{[28]}$ standard, with some modifications. Before the analysis, the samples were stored at $25^{\circ} \mathrm{C}$ and $53 \% \mathrm{RH}$ for $48 \mathrm{~h}$. Each film sample was fixed in the circular opening of a permeation cell with a $60 \mathrm{~mm}$ internal diameter, and silicone grease was applied to ensure that humidity migration occurred only through the film. The interior of the cell was filled with a magnesium chloride solution $\left(\mathrm{MgCl}_{2} / 32.8 \% \mathrm{RH}\right)$ and the device was stored at $25^{\circ} \mathrm{C}$ in a desiccator to maintain a $42 \%$ $\mathrm{RH}$ gradient across the film. A saturated sodium chloride solution $(\mathrm{NaCl})$ was used in the desiccator to provide $75.3 \%$ $\mathrm{RH}$. The samples were weighed every $3 \mathrm{~h}$ during the $72 \mathrm{~h}$ of testing time. Changes in the weight of the cell or mass gain $(\mathrm{m})$ were plotted as a function of time $(\mathrm{t})$. The slope of the line was calculated by linear regression $\left(\mathrm{R}^{2}>0.98\right)$, and the water vapour permeation ratio (WVPR) was obtained with Equation 1:

$$
W V P R=\left(\frac{m}{t}\right) \cdot\left(\frac{1}{A}\right)
$$

Table 1. Concentration of the components in the formulations.

\begin{tabular}{|c|c|c|c|c|}
\hline \multirow[b]{2}{*}{ Samples } & \multicolumn{4}{|c|}{ Components } \\
\hline & 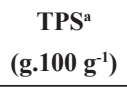 & $\begin{array}{c}\text { PBAT } \\
\left(\mathrm{g} .100 \mathrm{~g}^{-1}\right) \\
\end{array}$ & $\begin{array}{c}\text { MCC } \\
\text { (g.100 } \mathrm{g}^{-1} \text { TPS/PBAT) }\end{array}$ & $\begin{array}{r}\text { Water }^{\mathrm{b}} \\
(\mathrm{mL})\end{array}$ \\
\hline $\mathrm{MCC} 0$ & 56 & 44 & 0.0 & 0.0 \\
\hline MCC4 & 56 & 44 & 4.0 & 9.6 \\
\hline MCC7 & 56 & 44 & 7.0 & 16.8 \\
\hline MCC10 & 56 & 44 & 10.0 & 24.0 \\
\hline
\end{tabular}

aContaining 27g glycerol/100g starch; ${ }^{\mathrm{b} C a l c u l a t e d}$ as $2.4 \mathrm{~mL} / \mathrm{g} \mathrm{MCC}$; The numbers in the codes of the samples represent the level of added MCC. 
where $m / t$ is the angular coefficient of the curve and $A$ is the sample permeation area.

The WVP $\left(\mathrm{g} \cdot \mathrm{s}^{-1} \cdot \mathrm{m}^{-1} \cdot \mathrm{Pa}^{-1}\right)$ was calculated using Equation 2:

$$
W V P=W V P R . s t / s p\left(R H_{1}-R H_{2}\right)
$$

where $s t$ is the mean sample thickness (m), sp is the water vapour saturation pressure at the assay temperature $(\mathrm{Pa})$, $\mathrm{RH}_{1}$ is the relative humidity of the desiccator and $\mathrm{RH}_{2}$ is the relative humidity in the interior of the permeation cell. These tests were conducted in duplicate.

\subsubsection{Weight Loss in Water (WLW)}

The weight loss in water was determined according to Olivato et al. ${ }^{[29]}$. Samples were previously dried for three days in a desiccator containing anhydrous $\mathrm{CaCl}_{2}(0 \% \mathrm{RH})$. After weighing, the films were immersed in distilled water, maintaining a proportion of 30:1 (water/sample), for $48 \mathrm{~h}$ at $25^{\circ} \mathrm{C}$. The samples were then removed and dried at $105^{\circ} \mathrm{C}$ for $4 \mathrm{~h}$, and the weight of the conditioned specimen after treatment was used to determine the $\%$ weight loss in water. These tests were conducted in triplicate.

\subsubsection{Scanning Electron Microscopy (SEM)}

A scanning electron microscope FEI, model Quanta 200 (Hillsboro, USA) was used to observe the fractured surface of the blown film samples. The samples were submerged in liquid nitrogen and then broken (cryogenic fracture). Before coating with a gold layer, the samples were stored at $25^{\circ} \mathrm{C}$ in a desiccator with silica gel $(\approx 0 \% \mathrm{RH})$ for 3 days. The coating was produced with a Sputter Coater (BAL-TEC SCD 050). Images were taken of the fractured surface and surface of films at a magnification of $1600 x$ and $800 x$, respectively.

\subsubsection{Statistical analysis}

The data were analysed using STATISTICA 8.0 software (Statsoft, Oklahoma), with analysis of variance (ANOVA) and Tukey's test at a 5\% significance level.

\section{Results and Discussions}

\subsection{Mechanical properties and density}

The mechanical properties and density of the films are expressed at Table 2. With a separate behaviour, the sample with greater proportions of MCC (MCC10) presented the lower tensile strength $(4.6 \pm 0.1 \mathrm{MPa})$ and elongation at break $(147 \pm 34 \%)$ and higher Young's modulus (79.2 $\pm 13.6 \mathrm{MPa})$.
Comparing the samples without $\mathrm{MCC}(\mathrm{MCC} 0)$ and $\mathrm{MCC} 4$, no significant differences between these samples were observed, for all the analysed parameters.

The increase of MCC content from 4 to $10 \% \mathrm{wt}$ reduces the tensile strength and elongation at break of the films, from $6.5 \pm 0.1$ to $4.6 \pm 0.1 \mathrm{MPa}$ and from $579 \pm 27$ to $147 \pm 34 \%$, respectively. This fact occurred as a result of the formation of cellulose agglomerates when higher concentration of this component was used, which reduced the reinforcing efficiency. The SEM images (Figure 1) confirm these results.

The rigidity of the material, represented for the Young's modulus, increased from 19.8 MPa (MCC0) for 79.2 $\mathrm{MPa}$ (MCC10). This effect can be related to the formation of a network structure above the percolation threshold produced by the cellulose fibres by means of hydrogen bond interactions ${ }^{[18,30]}$.

According to Ibrahim et al..$^{[31]}$, the Young's modulus of the polymers may increase by the reinforcement effect of the cellulose fibres while the tensile strength may not be improved, or even be reduced, due the flocculation of the cellulose fibres, which is in accordance with the results of the present work.

Similar effects were reported by Ma et al. ${ }^{[32]}$ for thermoplastic pea starch composites containing $12 \% \mathrm{wt}$ of MCC. Mathew et al. ${ }^{[21]}$ analysed the effect of MCC in poly (lactic acid) (PLA) matrix and observed that greater concentrations of MCC in the samples (from 10 to $25 \% \mathrm{wt}$ ) reduced the tensile strength and elongation at break and increased the Young's modulus.

Considering the density of the films, no significant differences were recorded between the formulations. Despite the lower density of the fibres, the concentrations used in this work ranged from $4-10 \% \mathrm{wt}$ and were not sufficient to affect the density of the materials. A possible cause of this is related to the absence of compaction of the polymeric chains with the inclusion of MCC (as can be observed in the Figure 1).

\subsection{Water Vapour Permeability and Weight Loss in Water}

Opposite to the effects of MCC in the mechanical properties, the addition of these fibres did not influence the water vapour permeability (WVP) of the films, even at highest concentrations, as showed at Figure 2.

The presence of high concentrations of the fibres probably introduces a tortuous path, which makes more difficult the water diffusion through the polymeric matrix ${ }^{[33]}$. According to

Table 2. Mechanical properties and density of the films.

\begin{tabular}{|c|c|c|c|c|}
\hline \multirow[b]{2}{*}{ Formulations* } & \multicolumn{4}{|c|}{ Properties } \\
\hline & $\begin{array}{c}\text { Tensile strength } \\
\text { (MPa) }\end{array}$ & $\begin{array}{c}\text { Elongation at break } \\
(\%)\end{array}$ & $\begin{array}{c}\text { Young's modulus } \\
\text { (MPa) }\end{array}$ & $\begin{array}{l}\text { Density } \\
\left(\mathrm{g} / \mathrm{cm}^{3}\right)\end{array}$ \\
\hline $\mathrm{MCCO}$ & $6.9 \pm 0.3^{\mathrm{a}}$ & $568 \pm 53^{\mathrm{a}}$ & $19.8 \pm 0.6^{b}$ & $1.03 \pm 0.01^{\mathrm{a}}$ \\
\hline MCC4 & $6.5 \pm 0.1^{\mathrm{a}}$ & $579 \pm 27^{\mathrm{a}}$ & $23.3 \pm 0.9^{b}$ & $1.04 \pm 0.02^{\mathrm{a}}$ \\
\hline MCC7 & $5.7 \pm 0.6^{b}$ & $448 \pm 86^{b}$ & $25.3 \pm 1.4^{\mathrm{b}}$ & $0.96 \pm 0.06^{\mathrm{a}}$ \\
\hline MCC10 & $4.6 \pm 0.1^{\mathrm{c}}$ & $147 \pm 34^{c}$ & $79.2 \pm 13.6^{\mathrm{a}}$ & $0.98 \pm 0.05^{\mathrm{a}}$ \\
\hline
\end{tabular}

*Numbers in the formulation codes are concerning MCC content (g.100 $\left.\mathrm{g}^{-1} \mathrm{TPS} / \mathrm{PBAT}\right)$; Results express in (mean \pm standard deviation); Different letters in the same column indicate significant differences $(\mathrm{p} \leq 0.05)$ according to the Tukey's test. 

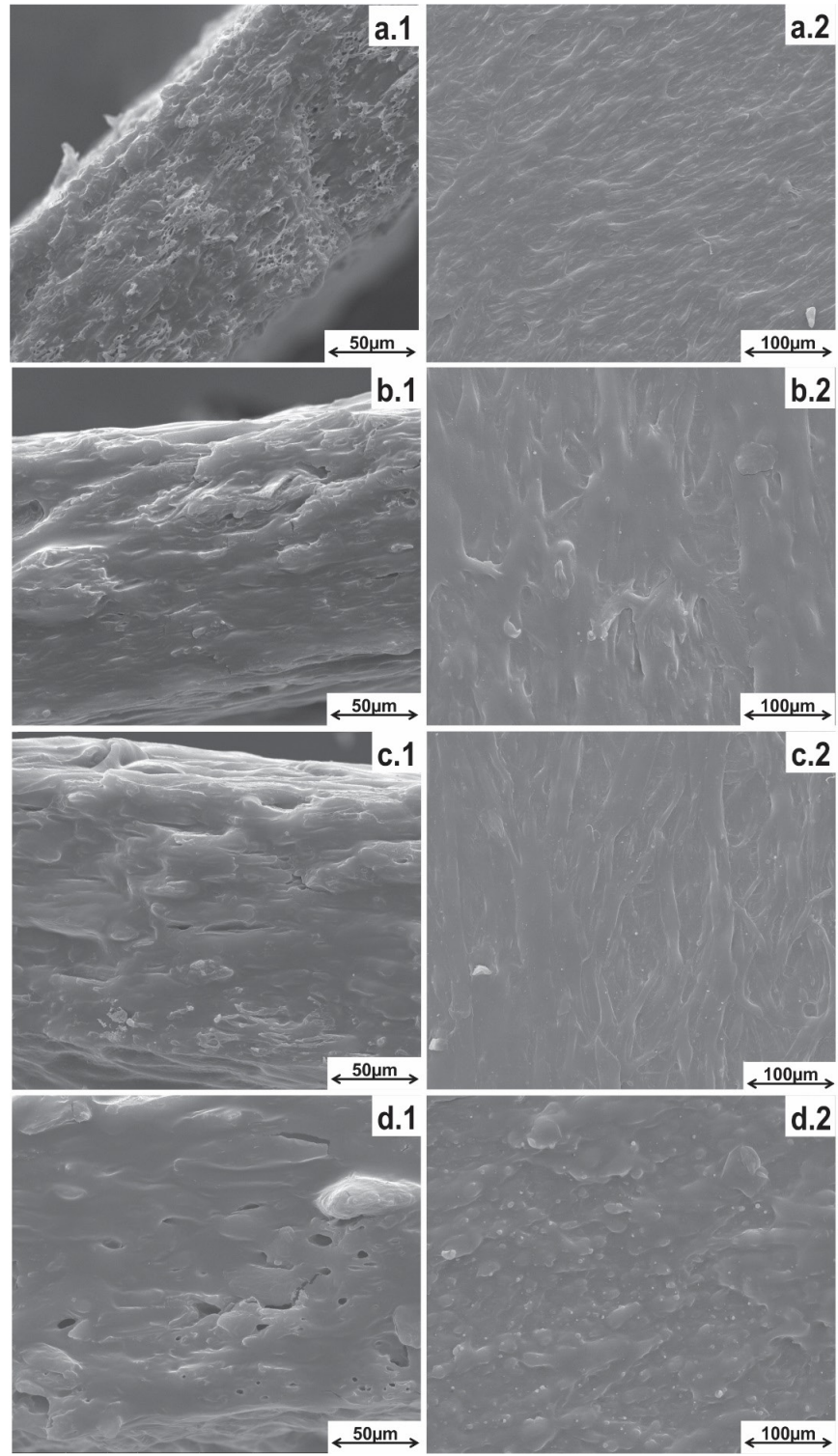

Figure 1. SEM images of the fractures (1) (1600x magnification) and surfaces (2) (800x magnification) of the samples: (a) MCC0; (b) MCC4; (c) MCC7; (d) MCC10.

Dogan and $\mathrm{McHugh}^{[34]}$, with the incorporation of cellulose fibres a reduction of the coefficient of water diffusion is expected since that the diffusion process into the matrix depends on the available pathways for the water molecules. However, a slight reduction on the diffusion coefficient was not sufficient to change the water vapour permeability of the films, as evidenced in the results of the present work.

On the other hand, Kunanopparat et al. ${ }^{[35]}$ reported that the addition of hemp and wood fibres in wheat gluten/glycerol composites reduced the water sensibility of the materials. Also Ma et al. ${ }^{[32]}$ found similar results for thermoplastic pea starch composites containing MCC. The various processing techniques (extrusion, compression moulding, and casting), polymeric matrices, type and concentrations of the fibres can explain the different effects of the cellulose fibres in the water vapour permeability of the composites.
The Figure 2 presents the \% of weight loss in water (WLW) of the samples. All the samples presented significant distinct results. While the formulation MCC0, without microcrystalline cellulose, exhibited a weight loss in water of $12.75 \pm 0.09 \%$, the inclusion of MCC in concentrations of 7 and $10 \%$ wt reduced the WLW of the films. This reduction was dependent of the concentration of the MCC at the formulations, with greatest values for WLW observed for the MCC10 (containing 10\% wt of MCC). This behaviour could be associated to the less hydrophilic character of the cellulose, when compared to the $\operatorname{starch}^{[36,37]}$. The molecules of cellulose, due their linear structure, are able to perform intra and intermolecular hydrogen bonds, resulting in the formation of a crystalline structure which is totally insoluble in water ${ }^{[22,38]}$. In the samples containing greater proportions of $\mathrm{MCC}$, the concentration of starch is lower, i.e., there 


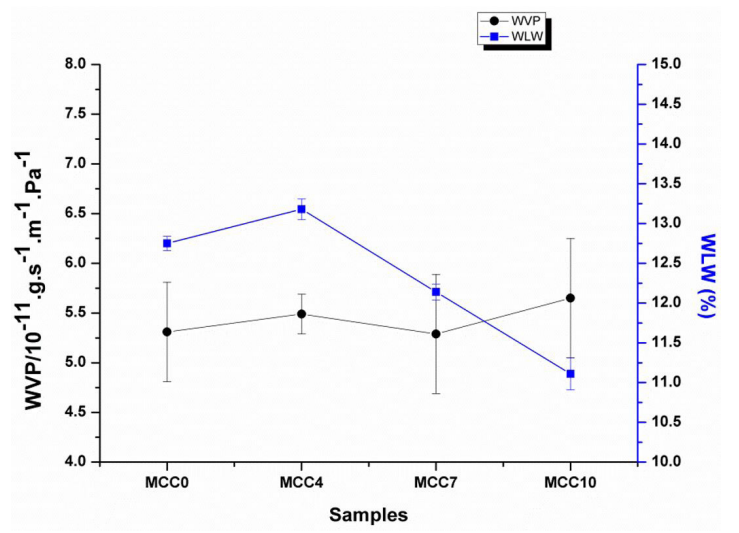

Figure 2. Water Vapour Permeability (WVP) and Weight Loss in Water (WLW) of the films.

are a substitution of a more soluble molecule ( starch) for a less soluble one (cellulose), which results in a reduction of WLW of the samples.

On the other hand, the MCC4 sample showed an opposite behaviour, i.e., the weight loss in water $(13.18 \pm 0.15 \%)$ was greater than the sample MCC0. A possible reason for this could be related to the easier removal of the MCC from the matrix structure, due to the starch solubilisation. Thus, even being insoluble, MCC stayed dispersed at the water. This explanation is valid only for low MCC contents $(\leq 5 \%)$, as reported by Reis et al. ${ }^{[24]}$.

\subsection{Scanning Electron Microscopy (SEM)}

The fracture and surface SEM images are presented at Figure 1, with magnification of 1600x and 800x, respectively. Under high temperature, shear and in the presence of a plasticiser, the starch granules were completely disrupted and no residual granules could be observed at SEM images. It is possible to notice a uniform dispersion of MCC in the starch/PBAT polymeric matrix, in the films with lower MCC concentration (Figure 1b.2 and c.2), however, the inclusion of MCC changed the films structure.

Greater concentrations of MCC added to the films led to the occurrence of micropores, as evidenced at SEM images (Figure 1c.1 and d.1). This effect was more pronounced in the films containing 7 and 10\% wt of MCC (MCC7 and MCC10). Oriented beams were observed at surface images (Figure 1a.2, b.2 and c.2), corresponding to the MCC0, MCC4 and MCC7, respectively. In a different way, the beams disappeared at surface image of the sample MCC 10 (Figure 1d.2), which, on the other hand, presented some aggregates.

In the Figure 1c.1 and d.1 images, some empty spaces were identified in the starch/PBAT matrix, which indicates weak or none interfacial adhesion between the matrix and MCC, when it was added in higher concentrations. A similar result was demonstrated by Mathew et al. ${ }^{[21]}$, studying PLA/ MCC films, indicating no interfacial adhesion of MCC in the PLA matrix. Santos and Tavares ${ }^{[39]}$ also developed PLA/MCC films and found in the SEM images that the dispersion of the MCC is relatively poor, due the self-aggregation of their molecules and the hydrophobic nature of the polymeric matrix. In the present work, the polymeric matrix contains thermoplastic starch (hydrophilic) and also PBAT, with hydrophobic character, which contributed to a low interfacial adhesion of the MCC in this matrix.

\section{Conclusion}

The addition of MCC in starch/PBAT films was successful, considering the low thickness characteristic of the materials produced by blown extrusion, which makes more difficult the processability of the films, since the MCC particles represents more fragile points in the matrix structure.

Using greater proportions of $\mathrm{MCC}$, a significant increase of the rigidity of starch/PBAT blown films was observed, but nevertheless, no contribution can be noticed in the tensile strength.

The occurrence of micropores, identified at SEM images, mostly at the samples with higher MCC content, did not affect the water vapour permeability of the films. The SEM images also showed that MCC tended to form some agglomerates when used at higher concentrations $(10 \% \mathrm{wt})$.

The blown extrusion process could have influenced the results of the films, considering that most of the materials studied and produced with MCC frequently use other techniques, as casting or compression moulding, to obtain biodegradable sheets. So, to make viable the use of MCC in the blown films, some adjustments in the process must be focused in future studies, such as a treatment in the MCC particles to improve their dispersion/compatibility when used at content higher than 5\% wt and, consequently, improve the tensile strength and water vapour permeability of the biodegradable films.

\section{Acknowledgements}

The authors thank CAPES, CNPq and Fundação Araucária for financial and fellowship support.

\section{References}

1. Woggum, T., Sirivongpaisal, P., \& Wittaya, T. (2015). Characteristics and properties of hydroxyproprylated rice starch based biodegradable films. Food Hydrocolloids, 50, 54-64. http://dx.doi.org/10.1016/j.foodhyd.2015.04.010.

2. Mello, L. R. P. F., \& Mali, S. (2010). Use of malt bagasse to produce biodegradable baked foams made from cassava starch. Industrial Crops and Products, 55, 187-193. http:// dx.doi.org/10.1016/j.indcrop.2014.02.015.

3. Ortega-Toro, R., Contreras, J., Talens, P., \& Chiralt, A. (2015). Physical and structural properties and thermal behaviour of starch-poly(E-caprolactone) blend films for food packaging. Food Packaging and Shelf Life, 5, 10-20. http://dx.doi. org/10.1016/j.fpsl.2015.04.001.

4. Li, C., Luo, J., Qin, Z., Chen, H., Gao, Q., \& Li, J. (2015). Mechanical and thermal properties of microcrystalline cellulose-reinforced soy protein isolate-gelatin eco-friendly films. Royal Society of Chemistry Advances, 5, 56518-56525. http://dx.doi.org/10.1039/c5ra04365d. 
5. Araujo-Farro, P. C., Podadera, G., Sobral, P. J. A., \& Menegalli, F. C. (2010). Development of films based on quinoa (Chenopodium quinoa, Willdenow) starch. Carbohydrate Polymers, 81(4), 839-848. http://dx.doi.org/10.1016/j.carbpol.2010.03.051.

6. Teixeira, E. M., Pasquini, D., Curvelo, A. A. S., Corradini, E., Belgacem, M. N., \& Dufresne, A. (2009). Cassava bagasse cellulose nanofibrils reinforced thermoplastic cassava starch. Carbohydrate Polymers, 78(3), 422-431. http://dx.doi. org/10.1016/j.carbpol.2009.04.034.

7. Tang, X., \& Alavi, S. (2011). Recent advances in starch, polyvinyl alcohol based polymer blends, nanocomposites and their biodegradability. Carbohydrate Polymers, 85(1), 7-16. http://dx.doi.org/10.1016/j.carbpol.2011.01.030.

8. Müller, C. M. O., Yamashita, F., \& Laurindo, J. B. (2008). Evaluation of the effects of glycerol and sorbitol concentration and water activity on the water barrier properties of cassava starch films through a solubility approach. Carbohydrate Polymers, 72(1), 82-87. http://dx.doi.org/10.1016/j.carbpol.2007.07.026.

9. Brandelero, R. P. H., Yamashita, F., \& Grossmann, M. V. E. (2010). The effect of surfactant tween 80 on the hydrophilicity, water vapor permeation, and the mechanical properties of cassava starch and poly(butylenes adipate-co-terephthalate) (PBAT) blend films. Carbohydrate Polymers, 82(4), 11021109. http://dx.doi.org/10.1016/j.carbpol.2010.06.034.

10. Soares, F. C., Yamashita, F., Müller, C. M. O., \& Pires, A. T. N. (2014). Effect of cooling and coating on thermoplastic starch/ poly(lactic acid) blend sheets. Polymer Testing, 33, 34-39. http://dx.doi.org/10.1016/j.polymertesting.2013.11.001.

11. Olivato, J. B., Marini, J., Pollet, E., Yamashita, F., Grossmann, M. V. E., \& Avérous, L. (2015). Elaboration, morphology and properties of starch/polyester nano-biocomposites based on sepiolite clay. Carbohydrate Polymers, 118, 250-256. PMid:25542131. http://dx.doi.org/10.1016/j.carbpol.2014.11.014.

12. Shirai, M. A., Müller, C. M. O., Grossmann, M. V. E., \& Yamashita, F. (2015). Adipate and citrate esters as plasticizers for poly(lactic acid)/thermoplastic starch sheets. Journal of Polymers and the Environment, 23(1), 54-61. http://dx.doi. org/10.1007/s10924-014-0680-9.

13. Olivato, J. B., Nobrega, M. M., Muller, C. M. O., Shirai, M. A., Yamashita, F., \& Grossmann, M. V. E. (2013). Mixture design applied for the study of the tartaric acid effect on starch/ polyester films. Carbohydrate Polymers, 92(2), 1705-1710. PMid:23399209. http://dx.doi.org/10.1016/j.carbpol.2012.11.024.

14. Park, H. M., Li, X., Jin, C. Z., Park, C. Y., Cho, W. J., \& Ha, C. S. (2002). Preparation and properties of biodegradable thermoplastic starch/clay hybrids. Macromolecular Materials and Engineering, 287(8), 553-558. http://dx.doi.org/10.1002/14392054(20020801)287:8<553::AID-MAME553>3.0.CO;2-3.

15. Follain, N., Joly, C., Dole, P., Roge, B., \& Mathlouthi, M. (2006). Quaternary starch based blends: influence of fourth component addition to the starch/water/glycerol system. Carbohydrate Polymers, 63(3), 400-407. http://dx.doi. org/10.1016/j.carbpol.2005.09.008.

16. Müller, C. M. O., Laurindo, J. B., \& Yamashita, F. (2009). Effect of cellulose fibers on the crystallinity and mechanical properties of starch-based films at different relative humidity values. Carbohydrate Polymers, 77(2), 293-299. http://dx.doi. org/10.1016/j.carbpol.2008.12.030.

17. Priya, B., Gupta, V. K., Pathania, D., \& Singha, A. S. (2014). Synthesis, characterization and antibacterial activity of biodegradable starch/PVA composite films reinforced with cellulosic fibre. Carbohydrate Polymers, 109, 171-179. PMid:24815414. http://dx.doi.org/10.1016/j.carbpol.2014.03.044.

18. Sun, X., Lu, C., Liu, Y., Zhang, W., \& Zhang, X. (2014). Melt-processed poly(vinyl alcohol) composites filled with microcrystalline cellulose from waste cotton fabrics.
Carbohydrate Polymers, 101, 642-649. PMid:24299821. http:// dx.doi.org/10.1016/j.carbpol.2013.09.088.

19. Oliveira, T. G., Makishi, G. L. A., Chambi, H. N. M., Bittante, A. M. Q. B., Lourenço, R. V., \& Sobral, P. J. A. (2015). Cellulose fiber reinforced biodegradable films based on proteins extracted from castor bean (Ricinus communis L.) cake. Industrial Crops and Products, 67, 355-363. http://dx.doi.org/10.1016/j. indcrop.2015.01.036.

20. Venables, A. C., Buliga, G. S., Dell, S. M., \& Colliopoulos, J. A. (2000). US Patent 6,037,380. Ultra-fine microcrystalline cellulose compositions process. Philadelphia: FMC Corporation.

21. Mathew, A. P., Oksman, K., \& Sain, M. (2005). Mechanical Properties of Biodegradable Composites from Poly Lactic Acid (PLA) and Microcrystalline Cellulose (MCC). Journal of Applied Polymer Science, 97(5), 2014-2025. http://dx.doi. org/10.1002/app.21779.

22. Bemiller, J. N., \& Huber, K. C. (2010). Carboidratos. In S. Damodaran, K. L. Parkin \& O. R. Fennema. Química de alimentos de Fennema (4th ed., pp. 75-130). Porto Alegre: Artmed.

23. Haafiz, M. K. M., Hassan, A., Zakaria, Z., Inuwa, I. M., Islam, M. S., \& Jawaid, M. (2013). Properties of polylactic acid composites reinforced with oil palm biomass microcrystalline celulose. Carbohydrate Polymers, 98(1), 139-145. PMid:23987327. http://dx.doi.org/10.1016/j.carbpol.2013.05.069.

24. Reis, M. O., Zanela, J., Olivato, J., Garcia, P. S., Yamashita, F., \& Grossmann, M. V. E. (2014). Microcrystalline cellulose as reinforcement in thermoplastic starch/poly(butylene adipate-coterephthalate) films. Journal of Polymers and the Environment, 22(4), 545-552. http://dx.doi.org/10.1007/s10924-014-0674-7.

25. Rafiee, Z., \& Keshavarz, V. (2015). Synthesis and characterization of polyurethane/microcrystalline cellulose bionanocomposites. Progress in Organic Coatings, 86, 190-193. http://dx.doi. org/10.1016/j.porgcoat.2015.05.013.

26. American Society for Testing and Material - ASTM. (2002). D882-02: standard test methods for tensile properties of thin plastic sheeting. West Conshohocken: ASTM.

27. Müller, C. M. O., Laurindo, J. B., \& Yamashita, F. (2011). Effect of nanoclay incorporation method on mechanical and water vapor barrier properties of starch-based films. Industrial Crops and Products, 33(3), 605-610. http://dx.doi.org/10.1016/j. indcrop.2010.12.021.

28. American Society for Testing and Material - ASTM. (1996). E96-00: standard test methods for water vapor transmission of materials. West Conshohocken: ASTM.

29. Olivato, J. B., Grossmann, M. V. E., Bilck, A. P., \& Yamashita, F. (2012). Effect of organic acids as additives on the performance of thermoplastic starch/polyester blown films. Carbohydrate Polymers, 90(1), 159-164. PMid:24751025. http://dx.doi. org/10.1016/j.carbpol.2012.05.009.

30. Samir, M. A. S. A., Alloin, F., \& Dufresne, A. (2005). Review of recent research into cellulosic whiskers, their properties and their application in nanocomposite field. Biomacromolecules, 6(2), 612-626. PMid:15762621. http://dx.doi.org/10.1021/ bm0493685.

31. Ibrahim, M. M., El-Zawawy, W. K., \& Nassar, M. A. (2010). Synthesis and characterization of polyvinyl alcohol/nanospherical cellulose particle films. Carbohydrate Polymers, 79(3), 694699. http://dx.doi.org/10.1016/j.carbpol.2009.09.030.

32. Ma, X., Chang, P. R., \& Yu, J. (2008). Properties of biodegradable thermoplastic pea starch/carboxymethyl cellulose and pea starch/microcrystalline cellulose composites. Carbohydrate Polymers, 72(3), 369-375. http://dx.doi.org/10.1016/j. carbpol.2007.09.002.

33. Kristo, E., \& Biliaderis, C. G. (2007). Physical properties of starch nanocrystal-reinforced pullulan films. Carbohydrate 
Polymers, 68(1), 146-158. http://dx.doi.org/10.1016/j. carbpol.2006.07.021.

34. Dogan, N., \& McHugh, T. H. (2007). Effects of microcrystalline cellulose on functional properties of hydroxy propyl methyl cellulose microcomposite films. Journal of Food Science, 72(1), 16-22. PMid:17995880. http://dx.doi.org/10.1111/j.17503841.2006.00237.x.

35. Kunanopparat, T., Menut, P., Morel, M.-H., \& Guilbert, S. (2008). Reinforcement of plasticized wheat gluten with natural fibers: from mechanical improvement to deplasticizing effect. Composites. Part A, Applied Science and Manufacturing, 39(5), 777-785. http://dx.doi.org/10.1016/j.compositesa.2008.02.001.

36. Ma, X., Yu, J., \& Kennedy, J. F. (2005). Studies on the properties of natural fibers-reinforced thermoplastic starch composites. Carbohydrate Polymers, 62(1), 19-24. http:// dx.doi.org/10.1016/j.carbpol.2005.07.015.
37. Müller, C. M. O., Laurindo, J. B., \& Yamashita, F. (2009). Effect of cellulose fibers addition on the mechanical properties and water vapor barrier of starch-based films. Food Hydrocolloids, 23(5), 1328-1333. http://dx.doi.org/10.1016/j.foodhyd.2008.09.002.

38. Silva, R., Haraguchi, S. K., Muniz, E. C., \& Rubira, A. F. (2009). Aplicações de fibras lignocelulósicas na química de polímeros e em compósitos. Química Nova, 32(3), 661-671. http://dx.doi.org/10.1590/S0100-40422009000300010.

39. Santos, F. A., \& Tavares, M. I. B. (2013). Preparo e caracterização de filmes obtidos a partir de poli (ácido lático) e celulose microcristalina. Polímeros: Ciência e Tecnologia, 23(2), 229235. http://dx.doi.org/10.1590/S0104-14282013005000021.

Received: Aug. 14, 2015

Revised: May 31, 2016

Accepted: June 29, 2016 